Article

\title{
Low intake of essential amino acids and other risk factors of stunting among under-five children in Malang City, East Java, Indonesia
}

\author{
Annisa Rizky Maulidiana, ${ }^{1}$ Endang Sutjiati ${ }^{2}$ \\ ${ }^{1}$ Department of Nutrition, Faculty of Medicine, Universitas Brawijaya, Malang; ${ }^{2}$ Department of Nutrition, \\ Poltekkes Kemenkes Malang, Indonesia
}

\begin{abstract}
Background: The lack of energy-protein intake has been shown to increase the risk of stunting in under-five children. The quality of protein in food is assessed by the completeness of amino acid content. This study aims to determine the amount of essential amino acid (EAAs) intake and other risk factors of stunting among under-five children.

Design and methods: A descriptive, case-control study was performed in the work area of Kedungkandang Health Center Malang. The subjects were 24-59-month-old children with a total of 23 stunted (height-for-age Z-score (HAZ) <-2 SD) and 57 normal children (HAZ $\geq-2 \mathrm{SD}$ ). Furthermore, the data were collected using anthropometric measurement, validated and pre-tested questionnaires, which were analyzed using multiple logistic regression.

Results: The intake of all the nine EAAs in stunted children was lower than that of non-stunted children. However, only histidine, isoleucine, and methionine were significantly different $(p<0.05)$. The significant risk factors of stunting include a family income per month fewer than the Regional Minimum Wages $[\mathrm{OR}=12.06,95 \% \mathrm{CI} 1.83-79.53]$, being underweight $[\mathrm{OR}=7.11$, $95 \%$ CI 1.49-33.93], breastfeeding of less than 6 months $[\mathrm{OR}=5.34,95 \% \mathrm{CI} 1.28-22.20]$, and the lack of EAA methionine intake [OR=0.14, 95\% CI 0.03-0.67].

Conclusions: Stunted children may not receive sufficient dietary intake of EAAs in their diet. Furthermore, the lack of EAAs intake, especially methionine, alongside low family income, underweight, lack of breastfeeding and variety in food consumption were the risk factors of stunting among under-five children in a selected Health Center in Malang City, Indonesia.
\end{abstract}

\section{Introduction}

Stunting is one of many emerging nutritional issues in developing countries, including Indonesia. In 2017, about 155 million children under five years of age were stunted, of which almost all were from low-income countries. ${ }^{1}$ According to the Indonesia basic health research data in 2018, its prevalence in Indonesia decreased within five years, from $37.2 \%$ in 2013 to $30.8 \%$ in 2018. ${ }^{2}$ However, based on the World Health Organization cut-off values of public health significance, ${ }^{3}$ this prevalence is considered high (30-39\%), meaning that stunting in Indonesia has to be treated as an urgent public health problem that requires full attention from the government.

The term 'stunting' refers to the nutritional status based on the HAZ (Height-for-age Z-score) index less than -2SD and is considered as the best indicator of measuring chronic malnutrition. ${ }^{4}$ Children with stunting suffer many health consequences, such as a lower survival rate, memory impairment, decreased cognitive and motor function, and development, as well as a higher chance to develop metabolic diseases and reduced productivity later in adulthood. ${ }^{5-7}$

The causes of stunting are multifaceted, intertwined, and related to each other. Stunting is directly caused by an inadequate nutrient intake, especially dietary carbohydrates and proteins, alongside the presence of infectious diseases. ${ }^{8}$ Dietary protein plays an important role in the body of children, specifically in brain growth and development. The quality of protein in food is assessed by the completeness of the amino acid (AA) content. ${ }^{9}$ The more complete the variety of AAs, the higher the value of a protein. ${ }^{10}$ There are nine types of AAs commonly known as essential amino acids (EAAs), which cannot be synthesized by the human body and must therefore be provided from the diet. These nine EAAs are histidine, isoleucine, leucine, lysine, methionine, phenylalanine, threonine, tryptophan, and valine..$^{9,10}$

The lack of EAA intake may cause disruption in the metabolic process which directly influences the linear growth of children. African children were at risk of stunting due to lesser consumption of EAA, such as tryptophan and lysine, in their diet. ${ }^{11}$ Similarly, stunted children in rural Malawi had lower levels of the nine EAAs present in serum, than children with normal growth status. The levels of circulating conditional EAAs (arginine, glycine, glutamine) and circulating non-EAAs (asparagine, glutamate, serine) were also significantly lower in stunted children compared to normal children. ${ }^{7}$ Nevertheless, the role of EAA intake among Indonesian children under the age of five is unknown.

Significance for public health

Stunting is a linear growth failure in children due to poor nutrition and recurrent infection. It is considered a public health problem worldwide. Furthermore, the quality of nutrition, not just quantity, is very important for child development. Protein quality is assessed by the presence of essential amino acids in food. However, research on the quality of protein intake in children is presently very limited. This study describes the importance of essential amino acid intake among other risk factors of stunting in under-five children. 
Aside from dietary and disease factors, the underlying risk factors of stunting include childbirth history, parenting style, parent's socioeconomic condition, and environmental factors. ${ }^{8}$ Furthermore, studies that focused on dietary protein quality, such as amino acid intake and its relation to stunting among children under five years of age is very limited, especially in Indonesia. By collectively investigating all the risk factors, it will be easier for stakeholders to make better decisions on prevention and intervention strategies. Therefore, this study aims to determine the levels of essential amino acids (EAAs) intake as well as other risk factors of stunting among under-five children.

\section{Design and Methods}

This was an observational study that involved a case-control design at the work area of the Health Center of Kedungkandang, Malang, conducted from August to October 2018. This place was chosen because it had the highest incidence of stunting in the entire city of Malang, East Java. According to the Malang City Health Office data in 2017, approximately 922 (5.9\%) out of 15,595 under-five children were stunted. The inclusion criteria were children aged 24 to 59 months at the time of the study, in good general health, and the mothers or caregivers were willing to be interviewed. Children which suddenly became sick or moved during the study had a medical condition, such as HIV, cancer, while other severe medical diagnoses were excluded. The purposive sampling method $^{12}$ was used with a ratio of 1:2 between the case and control group, $95 \%$ CI, $80 \%$ power, and accounted for $10 \%$ possible nonresponse. A total of eighty children with their mothers or caregivers participated in this study. Furthermore, the total cases of stunted children were 23 , while the control was 57 with stunting absent. The mother or caregiver was informed about the study after which they agreed to take part, by signing informed consent. This study was approved by the Ethical Committee of Politeknik Kesehatan Kemenkes Malang, Indonesia (No.: 435/KEPKPOLKESMA/2018).

The weight and height were measured by trained enumerators based on the WHO Multicentre Growth Reference Study guidelines. ${ }^{13}$ Body weight was measured to the nearest $0.1 \mathrm{~kg}$ using a portable electronic scale, while height was measured to the nearest $0.1 \mathrm{~cm}$ using a microtoise. The nutritional status of each child was calculated from the average of duplicate anthropometric measurements and determined using Z-scores (weight-for-age z-score (WAZ) and height-for-age z-score (HAZ) according to WHO Child Growth Standards (www.who.int/childgrowth/software/en/) with macros for SPSS version 6.0 and above. The classification of malnutrition (underweight and stunting) was defined based on -2.0 zscores below the median of the WHO Child Growth Standards, with the following cut-offs: stunting if $<-2$ HAZ (moderate stunting: $-3 \leq \mathrm{HAZ}<-2$; severe stunting: $\mathrm{HAZ}<-3$ ); underweight if $<-2$ WAZ (moderate underweight: $-3 \leq \mathrm{WAZ}<-2$; severe underweight: WAZ $<-3$.

A semi-quantitative food frequency questionnaire (SQ-FFQ) was used to assess the dietary intake of children. The SQ-FFQ form contained 118 commonly consumed foods, according to the Indonesian Food List of Essential Amino Acid Content ${ }^{14}$ from nine food groups, including cereal grains, starchy roots, legumes, vegetables, fruits, meat, seafood, eggs, milk, and milk products, as well as fats and oils.

The total intake of each food consumed was then entered into Nutrisurvey software (SEAMEO TROPMED RCCN-University of Indonesia, 2007) to estimate the daily energy and macronutrient intake (protein, fat, and carbohydrate), and essential amino acids
(EAAs). ${ }^{15}$ The macronutrient intake was determined by comparison with the standard requirements for children under five years of age using the 2013 Indonesian Nutrition Adequacy Rate and then categorized based on the Total Diet Survey. ${ }^{16,17}$ The cut-offs were as follows: i) Energy intake level: low, $70-<100 \%$ Energy Adequacy Rate (EAR); modest, $100-<130 \%$ EAR; high, $\geq 130 \%$ EAR; ii) Protein intake level: low, $80-<100 \%$ Protein Adequacy Rate (PAR); modest, $100-<120 \%$ PAR; high, $\geq 120 \%$ PAR; iii) Fat intake level: low, $<30 \%$; modest, 30-35\%; high, $>35 \%$; iv) Carbohydrate intake level: low, $<155 \mathrm{~g} /$ day; modest, 155-254 $\mathrm{g} /$ day; high, $>254 \mathrm{~g} /$ day.

The socio-economic status and demographic data of the household or parents were assessed through questionnaires. A structured questionnaire was administered to the mother or primary caretaker of each child, which required their personal and demographic information, such as age (verified by birth certificates, vaccination cards, or other formal documents) gender, their primary caretaker's age, educational status as well as the occupation of the parents or caretakers. The measurement of socioeconomic status reflects the necessary resources for achieving food security, child care, and a healthy environment.

The questionnaire was pre-tested using $10 \%$ of the sample size in another population. The data were collected by four trained nutritionist enumerators, and the supervisors checked all the filled questionnaires for completeness after data retrieval.

\section{Statistical analysis}

To compare the characteristics of children between stunting and non-stunting, the Chi-square, and independent-sample $t$-test were used. The bivariate analysis was performed for all risk factor variables to identify the ones associated with stunting and to obtain crude odds ratio (OR). Furthermore, significant risk factor variables $(\mathrm{p}<0.2)$ were put back together into the final model using the forward stepwise selection method to get an adjusted OR. The Odds ratios (95\% confidence intervals) were calculated to determine the association between risk factor variables and stunting multicollinearity and interaction.

\section{Results and Discussions}

Out of the 80 participants, $23(38 \%)$ were stunted children. There were no significant differences for the age and sex variables between stunted and non-stunted children (Table 1). Anthropometric measurements such as body weight, height, WAZ, and HAZ showed a significant difference $(\mathrm{p}<0.001)$. Furthermore, the mean of WAZ $(-2.21 \pm 1.08)$ and HAZ $(-3.08 \pm 1.02)$ indicated that the stunted children were in underweight $(<-2 \mathrm{SD})$ and severely stunted $(<-3 \mathrm{SD})$ categories.

As shown in Table 1, more than half of the stunted children had low energy and carbohydrate intake levels, compared to the nonstunted. Meanwhile, high protein intake levels were observed in all stunted children (100\%). Overall, the dietary intake of nine EAAs was lower in stunted children than the non-stunted. The significant differences were only obtained in EAA such as Histidine, Isoleucine, and Methionine, with $\mathrm{p}=0.035, \mathrm{p}=0.035$, and $\mathrm{p}=0.050$, respectively.

The educational level of mothers $(\mathrm{p}=0.032)$ and family income $(p=0.002)$ were significantly different between stunted and nonstunted children. Most mothers of stunted children attended junior high school, while the mothers of non-stunted children continued their education until college (40.3\%). Likewise, most families of non-stunted children $(45.6 \%)$ had a monthly income above the 
Table 1. Characteristics of study participants $(\mathrm{n}=\mathbf{8 0})$.

\begin{tabular}{|c|c|c|c|}
\hline & Stunted (n=23) n (\%) & Non-stunted $(\mathrm{n}=57) \mathrm{n}(\%)$ & p \\
\hline Age, months (mean \pm SD) & $30.87 \pm 8.91$ & $38.88 \pm 12.34$ & 0.072 \\
\hline $\begin{array}{l}\text { Gender } \\
\quad \text { Male }\end{array}$ & $11(47.8)$ & $32(56.1)$ & 0.622 \\
\hline $\begin{array}{l}\text { Anthropometry (mean } \pm \text { SD) } \\
\text { Birth weight, } \mathrm{kg} \\
\text { Birth length, cm } \\
\text { Body weight, } \mathrm{kg} \\
\text { Height, cm } \\
\text { WAZ } \\
\text { HAZ }\end{array}$ & $\begin{array}{c}2.89 \pm 0.34 \\
47.00 \pm 4.80 \\
10.01 \pm 1.26 \\
80.35 \pm 4.58 \\
-2.21 \pm 1.08 \\
-3.08 \pm 1.02\end{array}$ & $\begin{array}{c}3.11 \pm 0.50 \\
50.13 \pm 4.89 \\
14.38 \pm 4.12 \\
95.87 \pm 10.61 \\
-0.34 \pm 1.65 \\
-0.25 \pm 1.34\end{array}$ & $\begin{array}{l}0.036 \\
0.004 \\
<0.001 \\
<0.001 \\
<0.001 \\
<0.001\end{array}$ \\
\hline $\begin{array}{l}\text { Breastfeeding of } 6 \text { months } \\
\text { Yes }\end{array}$ & $17(73.9)$ & $26(45.6)$ & 0.022 \\
\hline $\begin{array}{l}\text { Infectious diseases last } 3 \text { months } \\
\text { Yes }\end{array}$ & $17(73.9)$ & $28(49.1)$ & 0.018 \\
\hline $\begin{array}{l}\text { Energy intake level } \\
\text { Low } \\
\text { Modest } \\
\text { High } \\
\end{array}$ & $\begin{array}{l}13(56.5) \\
2(8.7) \\
8(34.8)\end{array}$ & $\begin{array}{l}17(29.8) \\
20(35.1) \\
20(35.1)\end{array}$ & 0.270 \\
\hline $\begin{array}{l}\text { Protein intake level } \\
\text { Low } \\
\text { Modest } \\
\text { High }\end{array}$ & $23(100)$ & $\begin{array}{c}3(5.3) \\
3(5.3) \\
51(89.5)\end{array}$ & 0.030 \\
\hline $\begin{array}{l}\text { Fat intake level } \\
\text { Low } \\
\text { Modest } \\
\text { High }\end{array}$ & $\begin{array}{c}3(13) \\
7(30.4) \\
13(56.5)\end{array}$ & $\begin{array}{c}8(14) \\
15(26.3) \\
34(59.6)\end{array}$ & 0.932 \\
\hline $\begin{array}{l}\text { Carbohydrate intake level } \\
\text { Low } \\
\text { Modest } \\
\text { High }\end{array}$ & $\begin{array}{l}15(65.2) \\
7(30.4) \\
1(4.3)\end{array}$ & $\begin{array}{l}32(56.1) \\
18(31.6) \\
7(12.3)\end{array}$ & 0.530 \\
\hline $\begin{array}{l}\text { EAA intake, g/day (mean } \pm \text { SD) } \\
\text { Histidine } \\
\text { Isoleucine } \\
\text { Leucine } \\
\text { Lysine } \\
\text { Methionine } \\
\text { Phenylalanine } \\
\text { Threonine } \\
\text { Tryptophan } \\
\text { Valine } \\
\end{array}$ & $\begin{array}{l}1.36 \pm 0.42 \\
2.44 \pm 0.78 \\
4.25 \pm 5.30 \\
3.54 \pm 4.57 \\
1.17 \pm 1.55 \\
2.10 \pm 0.79 \\
2.15 \pm 0.68 \\
0.63 \pm 0.22 \\
2.78 \pm 0.85 \\
\end{array}$ & $\begin{array}{l}1.77 \pm 0.89 \\
3.16 \pm 1.55 \\
5.30 \pm 2.61 \\
4.57 \pm 2.46 \\
1.55 \pm 0.80 \\
3.03 \pm 1.49 \\
2.74 \pm 1.39 \\
0.81 \pm 0.41 \\
3.51 \pm 1.70\end{array}$ & $\begin{array}{l}0.038 \\
0.038 \\
0.140 \\
0.131 \\
0.050 \\
0.160 \\
0.073 \\
0.073 \\
0.069 \\
\end{array}$ \\
\hline $\begin{array}{l}\text { Age of mother, year } \\
18-25 \\
26-45 \\
>45\end{array}$ & $\begin{array}{c}5(21.7) \\
18(78.3) \\
-\end{array}$ & $\begin{array}{c}12(21.1) \\
44(77.2) \\
1(1.8)\end{array}$ & 0.815 \\
\hline $\begin{array}{l}\text { Mother's education level } \\
\text { Low } \\
\text { Modest } \\
\text { High }\end{array}$ & $\begin{array}{l}10(43.5) \\
10(43.5) \\
3(13.0)\end{array}$ & $\begin{array}{l}22(38.6) \\
12(21.1) \\
23(40.3)\end{array}$ & 0.032 \\
\hline $\begin{array}{l}\text { Mother's occupation } \\
\text { Not working } \\
\text { Working }\end{array}$ & $\begin{array}{c}19(82.6) \\
4(17.4)\end{array}$ & $\begin{array}{l}39(68.4) \\
18(31.6)\end{array}$ & 0.198 \\
\hline $\begin{array}{l}\text { Age of father, year } \\
\begin{array}{l}18-25 \\
26-45 \\
>45\end{array}\end{array}$ & $\begin{array}{c}1(4.3) \\
22(95.7) \\
\quad-\end{array}$ & $\begin{array}{c}5(8.8) \\
48(84.2) \\
4(7.0)\end{array}$ & 0.319 \\
\hline $\begin{array}{l}\text { Father's education level } \\
\text { Low } \\
\text { Modest } \\
\text { High }\end{array}$ & $\begin{array}{l}9(39.1) \\
5(21.7) \\
9(39.1)\end{array}$ & $\begin{array}{l}16(28.1) \\
14(24.6) \\
27(47.4)\end{array}$ & 0.624 \\
\hline $\begin{array}{l}\text { Father's occupation } \\
\text { Not working/labor } \\
\text { Service/trade }\end{array}$ & $\begin{array}{l}8(34.7) \\
11(47.8) \\
4(17.4)\end{array}$ & $\begin{array}{l}10(17.5) \\
24(42.1) \\
23(40.4)\end{array}$ & 0.089 \\
\hline 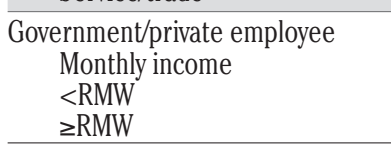 & $\begin{array}{c}21(91.3) \\
2(8.7)\end{array}$ & $\begin{array}{l}31(54.4) \\
26(45.6)\end{array}$ & 0.002 \\
\hline
\end{tabular}

Energy intake level: low, 70-<100\% Energy Adequacy Rate (EAR); modest, 100-<130\% EAR; high, $\geq 130 \%$ EAR; protein intake level: low, 80-<100\% Protein Adequacy Rate (PAR); modest, 100-<120\% PAR; high, $\geq 120 \%$ PAR; fat intake level: low, <30\%; modest, 30-35\%; high, $>35 \%$ Energy from fat intake; carbohydrate intake level: low, $<155 \mathrm{~g} /$ day; modest, $155-254 \mathrm{~g} /$ day; high, $>254 \mathrm{~g} /$ day; education level: low, less than or equal to complete primary school; modest: complete junior high school; high: complete senior high school/college; RMW, Regional Minimum Wage, Malang City per 2018 IDR $2.470 .073,29$ (Source: Malang City Labor Office, 2018). 
Malang Regional Minimum Wage (RMW) than the families of stunted children (8.7\%). The association between EAAs intake and the risk of stunting is shown in Table 2. From the adjusted or final regression model, it was observed that there are four variables related to the risk of stunting in under-five children: study participant (children) living with a family with a monthly income level less than RMW [adjusted odds ratio $(\mathrm{AOR})=12.06,95 \% \mathrm{CI} 1.83$ $79.53, \mathrm{p}=0.010$ ] were more likely to develop stunting than the ones living in a family with monthly income level above RMW. Underweight children [AOR $=7.11,95 \%$ CI 1.49 - 33.93, $\mathrm{p}=0.014$ ] were more likely to be stunted than normal-weight children. In addition, children with incomplete breastfeeding (less than six months) $[\mathrm{AOR}=5.34,95 \%$ CI $1.28-22.20, \mathrm{p}=0.021]$ were more likely to be stunted than children with complete breastfeeding for six months or more. Children lacking EAA intake, especially methionine $[\mathrm{AOR}=0.14,95 \%$ CI $0.03-0.67, \mathrm{p}=0.014$ ] were more likely to develop stunting.

This study investigated the amount of EAA intake and other variables such as risk factors of stunting in under-five children. It was observed that the intake of nine EAAs in stunted children was lower compared to non-stunted children. Specifically, three EAAs, namely histidine, isoleucine, and methionine were observed to be significantly lower. It was also observed that low family income, an underweight child, a breastfeeding duration below 6 months, and the lack of EAA methionine intake were the risk factors of stunting in under-five children.

This study showed that the intake of nine EAAs in stunted children tended to be lower than in non-stunted children, while only three EAAs (histidine, isoleucine, and methionine) were found to be significantly lower. Inadequate intake of EAAs causes nitrogen imbalance for protein synthesis which replaces all losses from protein turnover in the human body. ${ }^{18}$ The EAAs play various roles in human health, such as the regulation of various metabolic pathways to improve health in general, including growth and development, reproduction, and lactation function. Therefore, the insufficient intake of EAAs in children causes a detrimental effect on their physical growth and development, known as stunting. ${ }^{19}$ This agrees with a previous study which stated that stunted children had a significantly lower serum level of all nine essential amino acids compared to non-stunted children. ${ }^{7}$ The prior study involved a metabolomic approach using serum metabolite measurements in blood. Therefore, if this study were to use the same approach, it will also be observed that the circulating amino acids in stunted children are significantly lower than in non-stunted children. The amino acid requirement in children is high due to linear growth and a high risk of infections. ${ }^{20}$ Therefore, the lesser the intake, the lesser the circulating amino acids in the body.

In contrast, although EAAs intake was lower in the case group than the control, the level of dietary protein intake remained high (above the adequacy rate) in both groups. This was because the mean protein intake ( $\mathrm{g} /$ day) in the control group was higher than that of the stunted cases. Children in the stunted group consumed less variation of food, especially protein sources, compared to the control. For example, stunted children only ate eggs and did not like to eat other types of proteins and vegetables for several days. The complete nine EAAs required by the body must be provided from the diet, especially combinations of different types of proteinsource foods. ${ }^{21}$ Additionally, previous research ${ }^{22}$ showed that despite the higher EAAs intake in the control group than the cases, both were still lower than the WHO standard for amino acids requirements in human nutrition. ${ }^{23}$ The limited database of amino acid content for Indonesian food might play a role in the calculation of total EAAs intake in this study. The Nutrisurvey software was used to estimate the amount of food intake because it is the most popular, easy to use, and has a specific database of Indonesian food. ${ }^{15}$ However, the nutrients database including macro and micronutrients for certain food materials, especially processed foods is not complete, which could result in data underestimation.

This study showed that stunted children had low dietary carbohydrate and high dietary protein intake. It was assumed that the high level of protein intake was not used for growth but to cover the lack of energy from carbohydrate sources. Therefore, there were insufficient amounts of circulating amino acids to maintain the linear growth in the case group. ${ }^{7}$ The stunting of growth, defined as slow growth in a protein-deficient child compare to the one receives an adequate intake of protein. ${ }^{18}$ The adverse effects can be seen from protein-energy deficiency diseases, such as kwashiorkor and marasmus, which occur due to a lack of energy sources from food, and not a specific protein deficiency. However, in most cases found in developing countries, many children are stunted because their diet provides adequate energy but inadequate protein intake. ${ }^{18,20}$ It was also suggested that the requirement of protein intake for the maintenance of growth in children under-five is $0.66 \mathrm{~g} / \mathrm{kg} /$ day and $0.46 \mathrm{~g} / \mathrm{kg} /$ day, respectively. Therefore, protein intake has to meet the daily total protein requirement in order to achieve healthy, optimal growth, and development.

Further analysis showed that low family income, being underweight, a breastfeeding duration below 6 months, and lack of the essential amino acid methionine intake were the risk factors of stunting in the work area of Kedungkandang Health Center, Malang. A child from a family with an income lesser than the Malang RMW had a risk of stunting 12.1 times greater than one from a family with a monthly income level equal to or above the RMW. This result correlates with previous studies both in Indonesia and other countries, ${ }^{24-28}$ which analyzed the association of family income level and the nutritional status of under-five children, especially stunting. Previous studies showed that low socioeconomic status is a risk factor for stunting in under-five children.

Family income is involved with the ability of these households to fulfill their primary, secondary and tertiary needs. A high family income makes it easy to fulfill life needs, whereas a low income makes it more difficult. Low income affects the quality and quantity of food consumed by the family. ${ }^{24,27}$ Usually, the consumed foods will be less varied and less in amount, especially the ones mainly functional for their growth, such as protein sources for amino acids, vitamins, and minerals. These limitations will increase the risk of stunting in children, and low income-levels prevent effective nutritional improvement. Therefore, when a welleducated mother is not supported by sufficient income in the household, their attitude towards their child or children's health is affected. ${ }^{29}$

In this study, children with $\mathrm{WAZ}<-2$ or underweight children are 7.11 times more likely to experience stunting, compared to the ones with normal weight. An underweight condition is a composite indicator of child growth, while stunting is a specific indicator for chronic malnutrition. These indicators are interrelated in the measurement of child nutritional status, and the results showed that stunted children in this study were chronically malnourished, due to long term nutritional deficiencies. . $^{3,4}$

Likewise, children with a breastfeeding duration fewer than 6 months are 5.34 times more likely to experience stunting compared to the ones which received complete breastfeeding. Growth and development in children require the input of balanced and relatively large nutrients. However, the babies' ability to eat is determined by the state of the digestive tract which is still in the maturation stage. The only food that concurs with the state of the digestive tract of infants and fulfills their needs for the first few months is 
Table 2. Logistic regression of the association of amino acid intake and other determinant factors and stunting in under-five children.

\begin{tabular}{|c|c|c|c|c|c|c|}
\hline Variable & OR & $\begin{array}{l}\text { Crude } \\
95 \% \text { CI }\end{array}$ & p & OR & $\begin{array}{l}\text { Adjusted } \\
95 \% \mathrm{CI}\end{array}$ & p \\
\hline $\begin{array}{l}\text { EAA intake (g/day) } \\
\text { Histidine } \\
\text { Isoleucine } \\
\text { Leucine } \\
\text { Lysine } \\
\text { Methionine } \\
\text { Phenylalanine } \\
\text { Threonine } \\
\text { Tryptophan } \\
\text { Valine }\end{array}$ & $\begin{array}{l}0.41 \\
0.61 \\
0.79 \\
0.76 \\
0.37 \\
0.67 \\
0.61 \\
0.18 \\
0.67\end{array}$ & $\begin{array}{l}0.18-0.97 \\
0.38-0.99 \\
0.60-1.03 \\
0.56-1.02 \\
0.14-0.95 \\
0.42-1.06 \\
0.37-1.03 \\
0.03-1.00 \\
0.44-1.02\end{array}$ & $\begin{array}{l}0.042 \\
0.044 \\
0.079 \\
0.066 \\
0.039 \\
0.086 \\
0.065 \\
0.050 \\
0.063\end{array}$ & $\begin{array}{l}\text { NR } \\
\text { NR } \\
\text { NR } \\
\text { NR } \\
0.14 \\
\text { NR } \\
\text { NR } \\
\text { NR } \\
\text { NR }\end{array}$ & $\begin{array}{c}- \\
- \\
- \\
- \\
0.03-0.67 \\
- \\
- \\
- \\
-\end{array}$ & $\begin{array}{c}- \\
- \\
- \\
- \\
0.014 \\
- \\
- \\
- \\
-\end{array}$ \\
\hline $\begin{array}{l}\text { Energy intake level } \\
\text { Low } \\
\text { Modest } \\
\text { High }\end{array}$ & $\begin{array}{l}1.91 \\
0.25 \\
1.00\end{array}$ & $\begin{array}{l}0.64-5.70 \\
0.05-1.33 \\
\text { Ref. }\end{array}$ & $\begin{array}{l}0.245 \\
0.103\end{array}$ & $\begin{array}{l}\text { NR } \\
\text { NR }\end{array}$ & - & - \\
\hline $\begin{array}{l}\text { Protein intake level } \\
\text { Low } \\
\text { Modest } \\
\text { High }\end{array}$ & $\begin{array}{l}0.00 \\
0.00 \\
1.00\end{array}$ & $\begin{array}{l}0.00-0.00 \\
0.00-0.00 \\
\text { Ref. }\end{array}$ & $\begin{array}{l}0.999 \\
0.999\end{array}$ & $\begin{array}{l}\text { NR } \\
\text { NR }\end{array}$ & - & - \\
\hline $\begin{array}{l}\text { Fat intake level } \\
\text { Low } \\
\text { Modest } \\
\text { High }\end{array}$ & $\begin{array}{l}0.98 \\
1.22 \\
1.00\end{array}$ & $\begin{array}{l}0.23-4.28 \\
0.41-3.67 \\
\text { Ref. }\end{array}$ & $\begin{array}{l}0.979 \\
0.723\end{array}$ & $\begin{array}{l}\text { NR } \\
\text { NR }\end{array}$ & - & - \\
\hline $\begin{array}{l}\text { Carb intake level } \\
\text { Low } \\
\text { Modest } \\
\text { High }\end{array}$ & $\begin{array}{l}3.28 \\
2.72 \\
1.00\end{array}$ & $\begin{array}{l}0.37-29.12 \\
0.28-26.35 \\
\quad \text { Ref. }\end{array}$ & $\begin{array}{l}0.286 \\
0.387\end{array}$ & $\begin{array}{l}\mathrm{NR} \\
\mathrm{NR}\end{array}$ & - & - \\
\hline $\begin{array}{l}\text { Gender } \\
\text { Male } \\
\text { Female } \\
\text { Birth weight, kg } \\
\text { Birth length, cm } \\
\end{array}$ & $\begin{array}{l}1.40 \\
1.00 \\
0.36 \\
0.77\end{array}$ & $\begin{array}{l}0.53-3.69 \\
\text { Ref. } \\
0.12-1.11 \\
0.62-0.95\end{array}$ & $\begin{array}{l}0.500 \\
\\
0.075 \\
0.017\end{array}$ & $\begin{array}{l}\text { NR } \\
\text { NR } \\
\text { NR }\end{array}$ & $\begin{array}{l}- \\
- \\
-\end{array}$ & $\begin{array}{l}- \\
- \\
-\end{array}$ \\
\hline $\begin{aligned} \mathrm{WAZ} & \\
& <-2 \mathrm{SD} \\
& \geq-2 \mathrm{SD}\end{aligned}$ & $\begin{array}{l}9.27 \\
1.00\end{array}$ & $\begin{array}{c}2.86-30.08 \\
\text { Ref. }\end{array}$ & $<0.001$ & $\begin{array}{l}7.11 \\
1.00\end{array}$ & $\begin{array}{c}1.49-33.93 \\
\quad \text { Ref. }\end{array}$ & 0.014 \\
\hline $\begin{array}{l}\text { Breastfeeding } \\
\quad<6 \text { months } \\
\geq 6 \text { months }\end{array}$ & $\begin{array}{l}3.38 \\
1.00\end{array}$ & $\begin{array}{c}1.16-9.82 \\
\text { Ref. }\end{array}$ & 0.025 & $\begin{array}{l}5.34 \\
1.00\end{array}$ & $\begin{array}{c}1.28-22.20 \\
\text { Ref. }\end{array}$ & 0.021 \\
\hline $\begin{array}{l}\text { Inf. disease last } 3 \text { months } \\
\text { Yes } \\
\text { No }\end{array}$ & $\begin{array}{l}3.98 \\
1.00\end{array}$ & $\begin{array}{c}1.20-13.20 \\
\text { Ref. }\end{array}$ & 0.024 & NR & - & - \\
\hline $\begin{array}{l}\text { Mother's age, year } \\
\quad 18-25 \\
26-45 \\
>45\end{array}$ & $\begin{array}{l}0.00 \\
0.00 \\
1.00\end{array}$ & $\begin{array}{l}0.00-0.00 \\
0.00-0.00 \\
\text { Ref. }\end{array}$ & $\begin{array}{l}0.999 \\
0.999\end{array}$ & NR & - & - \\
\hline $\begin{array}{l}\text { Mother's education } \\
\text { Low } \\
\text { Modest } \\
\text { High }\end{array}$ & $\begin{array}{l}3.49 \\
6.39 \\
1.00\end{array}$ & $\begin{array}{l}0.85-14.37 \\
1.47-27.70 \\
\quad \text { Ref. }\end{array}$ & $\begin{array}{l}0.084 \\
0.013\end{array}$ & $\begin{array}{l}\text { NR } \\
\text { NR }\end{array}$ & - & - \\
\hline $\begin{array}{l}\text { Mother's occupation } \\
\text { Working } \\
\text { Not working }\end{array}$ & $\begin{array}{l}2.19 \\
1.00\end{array}$ & $\begin{array}{c}0.65-7.38 \\
\text { Ref. }\end{array}$ & 0.205 & NR & - & - \\
\hline $\begin{array}{l}\text { Father's age, year } \\
\quad \begin{array}{l}18-25 \\
26-45 \\
>45\end{array}\end{array}$ & $\begin{array}{l}0.00 \\
0.00 \\
1.00\end{array}$ & $\begin{array}{l}0.00-0.00 \\
0.00-0.00 \\
\text { Ref. }\end{array}$ & $\begin{array}{l}0.999 \\
0.999\end{array}$ & $\begin{array}{l}\text { NR } \\
\text { NR }\end{array}$ & - & - \\
\hline $\begin{array}{l}\text { Father's education Low } \\
\text { Modest } \\
\text { High } \\
1.00 \\
\end{array}$ & $\begin{array}{l}1.69 \\
1.07 \\
\text { Ref. }\end{array}$ & $\begin{array}{l}0.56-5.13 \\
0.30-3.81\end{array}$ & $\begin{array}{l}0.356 \\
0.915\end{array}$ & $\begin{array}{l}\text { NR } \\
\text { NR }\end{array}$ & - & $\begin{array}{l}- \\
-\end{array}$ \\
\hline $\begin{array}{l}\text { Father's occupation } \\
\text { Not working/labor } \\
\text { Service/trade } \\
\text { Gov.private employee }\end{array}$ & $\begin{array}{l}4.60 \\
2.64 \\
1.00\end{array}$ & $\begin{array}{l}1.12-18.87 \\
0.73-9.47 \\
\quad \text { Ref. }\end{array}$ & $\begin{array}{l}0.034 \\
0.138\end{array}$ & $\begin{array}{l}\text { NR } \\
\text { NR }\end{array}$ & - & - \\
\hline $\begin{array}{c}\text { Family income } \\
<\text { RMW } \\
\geq \text { RMW }\end{array}$ & $\begin{array}{l}8.81 \\
1.00\end{array}$ & $\begin{array}{c}1.89-41.13 \\
\text { Ref. }\end{array}$ & 0.006 & $\begin{array}{l}12.06 \\
1.00\end{array}$ & $\begin{array}{c}1.83-79.53 \\
\text { Ref. }\end{array}$ & 0.010 \\
\hline
\end{tabular}


breast milk. ${ }^{30}$ Children which do not get exclusive breastfeeding are at higher risk of lacking nutrients needed for the growth process, and an impaired growth results in stunting. ${ }^{24,31-34}$

Finally, the lack of EAAs in food sources, especially methionine is another risk factor for stunting. Children consuming lots of methionine sources are $86 \%$ more likely not to develop stunting compared to the ones which consume fewer methionine sources. Adequate research on amino acid intake in under-five children is still highly limited. However, similar studies that analyzed serum amino acid levels stated that stunted children had lower levels of nine essential AAs (histidine, isoleucine, leucine, lysine, methionine, phenylalanine, tryptophan, threonine and valine) than children with normal growth. ${ }^{7}$ Methionine plays a significant role in cellular growth, it sends growth signals to cells and catalyzes a metabolic program for cell proliferation. ${ }^{35,36}$ Food sources with high levels of methionine are animal protein, such as meat, fish, and eggs; plant seeds; and cereal grains. Legumes, despite their high protein density, contain low amounts of methionine. Furthermore, dietary proteins without sufficient amounts of methionine are not considered complete proteins. ${ }^{36}$ The quality of proteins is determined based on their ability to meet the requirements of the nine EAAs. $^{23}$ Complete proteins are usually provided from different kinds of animal sources, specifically meat, fish, eggs, and milk. However, nutrients from various types of food groups and not only animal proteins must be provided in adequate amounts and balanced nutrition, especially for children. Previous studies show that inadequate dietary diversity is a strong predictor of stunting. Therefore, further intervention efforts are required to address appropriate feeding practices by giving children a sufficient amount of diverse diet. . $^{34,37,38}$

This is one of few Indonesian studies which assessed the quality of protein by the amounts of EAAs intake in under-five children. This study was limited by the lack of minimum sample sizes in the case group. Only one Health Center in Malang was chosen, therefore it is not proper to generalize the risk factors of stunting, especially EAAs intake, type of food sources, and the overall purchasing power of the Malang population. Finally, the biochemical marker measurement, specifically blood serum, was not performed to validate the intake of EAAs. This is due to the relatively high cost, time taken for serum examination, and its burdensome nature to respondents.

\section{Conclusions}

This study showed that stunted children under-five had a lower intake of nine EAAs than non-stunted children in their diet, although the dietary protein intake remained high in both groups. Therefore, the quantity as well as the quality of protein is critical. The lack of EAAs intake, especially methionine, alongside low family income, underweight, lack of exclusive breastfeeding and less variety of foods were the risk factors of stunting among underfive children in a selected Health Center in Malang City. Therefore, the prevention and intervention to reduce stunting has to focus on these determinants. Multisectoral coordination and collaboration to establish an integrated nutritional program are highly necessary.
Correspondence: Annisa Rizky Maulidiana, Department of Nutrition, Faculty of Medicine, Universitas Brawijaya, Jl. Veteran Malang, 65145, East Java, Indonesia.

Tel. +62.341569117 - Fax: +62.341564755

E- mail: annisarizky@ub.ac.id

Key words: Children; essential amino acid; protein quality; stunting; under-five.

Contributions: ARM was involved from the inception to design, data acquisition, analysis and interpretation, drafting and editing the manuscript for final submission. Furthermore, ES was involved in the inception, design, analysis, interpretation, and revision of the manuscript. ARM and ES both wrote the manuscript and were responsible for its final content, and all authors read and approved the final manuscript.

Conflict of interests: The authors declare no potential conflict of interest.

Funding: This study was financially supported by Poltekkes Kemenkes Malang, Indonesia (Decree HK.02.03/1/4017/2018).

Acknowledgment: The authors express heartfelt gratitude to the Universitas Brawijaya and Poltekkes Kemenkes Malang for the support of this study. The authors are also grateful to the field data collectors. Finally, special thanks to the mothers and caregivers who participated in this study.

Ethical approval and consent to participate: All procedures were approved by the research ethics committee of Poltekkes Kemenkes Malang, Indonesia (No.: 435/KEPK-POLKESMA/2018).

Conference presentation: Part of this study was presented at the $1^{\text {st }}$ International Nursing and Health Sciences Symposium, November $13^{\text {th }}$ to $15^{\text {th }} 2020$, Brawijaya University, Malang, Indonesia.

Received for publication: 14 January 2021.

Accepted for publication: 15 March 2021.

(Copyright: the Author(s), 2021

Licensee PAGEPress, Italy

Journal of Public Health Research 2021;10:2161

doi:10.4081/jphr.2021.2161

This work is licensed under a Creative Commons Attribution NonCommercial 4.0 License (CC BY-NC 4.0).

\section{References}

1. UNICEF, WHO, World Bank Group. Levels and trends in child malnutrition. UNICEF / WHO / World Bank Group Joint Child Malnutrition Estimates. Key findings of the 2017 edition. New York: World Health Organization; 2017.

2. Ministry of Health Republic of Indonesia. Basic Health Research 2018. Jakarta, Indonesia; Ministry of Health Republic of Indonesia; 2018.

3. World Health Organization. Country Profile Indicators: Interpretation Guide. Nutrition Landscape Information System. Geneva: World Health Organization; 2010.

4. World Health Organization. Physical status: the use and interpretation of anthropometry. Report of a WHO Expert Committee. Geneva: World Health Organization; 1995.

5. Dewey KG, Begum K. Long-term consequences of stunting in early life. Matern Child Nutr 2011;7:5-18.

6. Black RE, Victora CG, Walker SP, et al. Maternal and child undernutrition and overweight in low-income and middleincome countries. Lancet 2013;382:427-51.

7. Semba RD, Shardell M, Sakr Ashour FA, et al. Child stunting 
is associated with low circulating essential amino acids. EBioMed 2016;6:246-52.

8. Satriawan E. [Strategi Nasional Percepatan Pencegahan Stunting 2018-2024 (National strategy for the acceleration of stunting prevention 2018-2024)].[in Indonesian]. National Team for the Acceleration of Poverty Reduction (TNP2K) Secretariat of the Vice President of the Republic of Indonesia. 2018. Available from: http://www.tnp2k.go.id/ filemanager/files/Rakornis 2018/Sesi 1_01_RakorStunting TNP2K_Stranas_22Nov2018.pdf

9. Wu G. Functional amino acids in growth, reproduction, and health. Adv Nutr 2010;1:31-7.

10. Almatsier S. [Prinsip Dasar Ilmu Gizi (Basic principles of nutrition)].[Book in Indonesian]. Jakarta: PT Gramedia Pustaka Utama; 2009.

11. Nuss ET, Tanumihardjo SA. Quality protein maize for Africa: Closing the protein inadequacy gap in vulnerable populations. Adv Nutr 2011;2:217-24.

12. Lwanga SK, Lemeshow S. Sample size determination in health studies: A practical manual. World Health Organization. Geneva, Switzerland; 1991

13. de Onis M, Onyango AW, Van den Broeck J, et al. Measurement and standardization protocols for anthropometry used in the construction of a new international growth reference. Food Nutr Bull 2004;25:S27-36.

14. Mukrie N, Chatijah S, Mosoar S, et al. Daftar komposisi zat gizi pangan Indonesia (List of nutritional composition of Indonesian food)].[in Indonesian]. Jakarta: Directorate of Community Nutrition, Center for Nutrition Research and Development; 1995.

15. Nutrisurvey. Nutrition surveys and calculations. Jakarta: Guidelines, software and additional Information. SEAMEO TROPMED RCCN-University of Indonesia; 2007.

16. Ministry of Health of the Republic of Indonesia. [Angka Kecukupan Gizi (AKG) (Nutritional Adequacy Rate (RDA)].[in Indonesian]. Jakarta: Ministry of Health of the Republic of Indonesia; 2013.

17. Ministry of Health of the Republic of Indonesia. [Studi Diet Total: Potret Pola Makan Penduduk Indonesia Saat Ini. Pertemuan Ilmiah Berkala Badan Litbangkes (Total Diet Study: A Portrait of Indonesia's Current Diet. Periodic Scientific Meeting of the National Research and Development Agency)].[in Indonesian]. Jakarta: Ministry of Health of the Republic of Indonesia; 2014.

18. Bender DA. Protein-energy malnutrition: problems of undernutrition. In: Introduction to nutrition and metabolism. New York: CRC Press Taylor \& Francis Group; 2004. p. 2336.

19. Pillai RR, Kurpad A V. Amino acid requirements in children and the elderly population. Br J Nutr 2012;108:S44-9.

20. Uauy R, Suri DJ, Ghosh S, et al. Low circulating amino acids and protein quality: An interesting piece in the puzzle of early childhood stunting. EBioMedicine 2016;8:28-9.

21. National Research Council (US) Subcommittee. The Tenth Edition of the Recommended Dietary Allowances. Recommended Dietary Allowances. Washington: National Academies Press; 1989.

22. Maulidiana AR, Dwipajati D. [Perbandingan Jumlah Asupan Asam Amino Antara Balita Stunting Dan Tidak Stunting Di Kecamatan Kedungkandang Kota Malang (Comparison of amino acid intake between stunting and non-stunting toddlers in Kedungkandang District, Malang City)].[Article in Indonesian]. J Inf Kesehat Indones 2019;5:12.

23. World Health Organization. Protein and amino acid requirements in human nutrition. Technical Report Series. Geneva, Switzerland: World Health Organization; 2007.

24. Khoirun N, Nadhiroh SR. [Faktor Yang Berhubungan Dengan Kejadian Stunting Pada Balita (Factors associated with the incidence of stunting in toddlers)].[Article in Indonesian]. Media Gizi Indones 2015;10:13-9.

25. Jesmin A, Yamamoto SS, Malik AA, et al. Prevalence and determinants of chronic malnutrition among preschool children: A cross-sectional study in Dhaka City, Bangladesh. J Heal Popul Nutr 2011;29:494.

26. Setiawan E, Machmud R, Masrul M. [Faktor-Faktor yang Berhubungan dengan Kejadian Stunting pada Anak Usia 24-59 Bulan di Wilayah Kerja Puskesmas Andalas Kecamatan Padang Timur Kota Padang Tahun 2018 (Factors associated with the incidence of stunting in children aged 24-59 months in the work area of the Andalas Public Health Center, Padang Timur District, Padang City in 2018)].[Article in Indonesian]. J Kesehat Andalas 2018;7:275-84.

27. Correia LL, Silva AC e, Campos JS, et al. Prevalence and determinants of child undernutrition and stunting in semiarid region of Brazil. Rev Saude Publica 2014;48:19-28.

28. Apriluana G, Fikawati S. [Analisis Faktor-Faktor Risiko terhadap Kejadian Stunting pada Balita (0-59 Bulan) di Negara Berkembang dan Asia Tenggara (Analysis of risk factors for stunting incidence in toddlers (0-59 months) in developing countries and Southeast Asia)].[Article in Indonesian]. Media Penelit dan Pengemb Kesehat 2018;28:247-56.

29. Semba RD, de Pee S, Sun K, et al. Effect of parental formal education on risk of child stunting in Indonesia and Bangladesh: a cross-sectional study. Lancet 2008;371:322-8.

30. Maryunani A. Ilmu Kesehatan Anak Dalam Kebidanan (Child health science in midwifery)].[ in Indonesian].Jakarta: Trans Info Media; 2010.

31. Sundari E, Nuryanto N. [Hubungan asupan protein, seng, zat besi, dan riwayat penyakit infeksi dengan z-score TB/U pada balita (The relationship between protein, zinc, iron intake, and a history of infectious disease with the z-score of TB in children under five)].[Article in Indonesian]. J Nutr Coll 2016;5:250-9.

32. Lestari W, Margawati A, Rahfiludin Z. [Faktor risiko stunting pada anak umur 6-24 bulan di kecamatan Penanggalan kota Subulussalam provinsi Aceh (Risk factors for stunting in children aged 6-24 months in the Penanggalan sub-district, Subulussalam city, Aceh province)].[Article in Indonesian]. Indones J Nutr 2014;3:37-45.

33. Fikadu T, Assegid S, Dube L. Factors associated with stunting among children of age 24 to 59 months in Meskan district, Gurage Zone, South Ethiopia: A case-control study. BMC Public Health 2014;14:800.

34. Paudel R, Pradhan B, Wagle RR, et al. Risk factors for stunting among children: A community based case control study in Nepal. Kathmandu Univ Med J 2012;10:18-24.

35. Walvekar AS, Srinivasan R, Gupta R, et al. Methionine coordinates a hierarchically organized anabolic program enabling proliferation. Mol Biol Cell 2018;29:3183-200.

36. Finkelstein JD. Methionine metabolism in mammals. J Nutr Biochem 1990;1:228-37.

37. Krasevec J, An X, Kumapley R, et al. Diet quality and risk of stunting among infants and young children in low- and middleincome countries. Matern Child Nutr 2017;13:e12430.

38. Mahmudiono T, Sumarmi S, Rosenkranz RR. Household dietary diversity and child stunting in East Java, Indonesia. Asia Pac J Clin Nutr 2017;26:317. 